4. Стратегия инновационного развития России до 2020г. Утверждена Распоряжением Правительства РФ от 8 декабря 2011 г. № 2227-р

5. Федеральный закон "О науке и государственной научно-технической политике" от 23.08.1996 N 127-Ф3

6. Шанахан, М. Технологическая сингулярность / пер. с англ. - М.: изд-во «Точка». Альпина Паблишер. 2017. - 256 с.

7. Шувалов, С.С. Стратегия инновационного развития России: результаты реализации первого этапа // Инноватика и экспертиза. 2015. Вып. 1 (4). С. 8 - 18.

\title{
Тенчиков А.А.
}

\section{Казахстан: индекс этнической мозаичности}

Санкт-Петербургский Государственный Университет (Россия, Санкт-Петербург)

doi: $10.18411 / \mathrm{lj}-10-2018-73$

idsp: 000001:lj-10-2018-73

В настоящее время Республика Казахстан является полиэтнической (многонациональной) страной: из более чем 18 млн. 100 тыс. его населения, казахи титульный этнос, составляли на начало 2018 года около 12 млн. 250 тыс. человек, то есть, $67,47 \%$ от общего населения, по официальной оценке Комитета по статистике Министерства национальной экономики Республики Казахстан. Крупнейшим национальным меньшинством этой страны являются русские - около 3 млн. 600 тыс. человек, то есть, чуть менее 20\% населения Казахстана. Из других крупных этнических меньшинств следует отметить узбеков - 3,18\%, украинцев - 1,53\%, уйгуров - 1,46\%, татар $-1,11 \%$ и немцев $-0,99 \%$.

Однако, при более детальном рассмотрении, а именно - на уровне регионов страны, можно обнаружить, что данное соотношение не сохраняется ни в одном из регионов. Например, в Кызылординской области казахи составляют более $96 \%$ населения, a русские - менее $2 \%$, в то время как в Северо-Казахстанской области доля русских превышает 49\%, - таким образом, казахи являются в этом регионе меньшинством. В Туркестанской области (на начало 2018 года, когда была произведена последняя официальная оценка численности населения Казахстана, эта область носила название Южно-Казахстанская, а Шымкент, который в настоящее время имеет статус города республиканского значения, входил в её состав) вторым по численности этносом являются узбеки - более $17 \%$ населения региона. На уровне муниципальных районов эти различия видны ещё сильнее: например, на юго-востоке Алматинской области существует Уйгурский район, в структуре населения которого представители этого этноса составляют более $57 \%$. Во многих районах областей северного и восточного Казахстана большинством являются русские.

Существуют различные способы оценить этническое многообразие той или иной территории. Один из них - индекс этнической мозаичности, который был предложен Б. М. Эккелем в 1976 году. Данный показатель вычисляется по следующей формуле:

$$
P=1-\sum_{i=1}^{m} n i^{2}
$$

где $\mathrm{m}$ - число этнических групп, a ni - доля представителей этнической группы в общем населении территории.

Чем ближе значение индекса этнической мозаичности к единице, тем менее однороден этнический состав населения исследуемой территории, и наоборот: нулевое значение соответствует полной моноэтничности.

Поскольку, как уже было сказано выше, Казахстан в настоящее время является полиэтничной страной с очень сложной структурой населения, поэтому следует рассчитать значение индекса этнической мозаичности не только для областей и городов 
республиканского значения, но и для отдельных районов. Индекс этнической мозаичности различных регионов Казахстана является объектом исследования. Цель вычисление и сравнение его значений. Основной задачей данной работы является анализ данных об этническом составе населения тех или иных регионов и районов Казахстана.

Для анализа использованы данные уже упоминавшегося выше Комитета по статистике Министерства национальной экономики Республики Казахстан. На его сайте имеется официальная оценка численности населения и, в частности, его этнической структуры на начало 2018 года. В рамках выполнения этой работы была проанализирована структура населения всех областей и муниципальных районов Казахстана. Результаты исследования по областям представлены в таблице 1.

Таблицุа 1

Значение индекса этнической мозаичности областей и городов республиканского значения Республики Казахстан

\begin{tabular}{|c|c|}
\hline Название региона & Индекс этнической мозаичности \\
\hline Город Астана & 0,37 \\
\hline Город Алма-Ата & 0,57 \\
\hline Акмолинская область & 0,63 \\
\hline Актюбинская область & 0,31 \\
\hline Алматинская область & 0,46 \\
\hline Атырауская область & 0,14 \\
\hline Восточно-Казахстанская область & 0,51 \\
\hline Жамбылская область & 0,46 \\
\hline Западно-Казахстанская область & 0,39 \\
\hline Карагандинская область & 0,61 \\
\hline Костанайская область & 0,66 \\
\hline Кызылординская область & 0,08 \\
\hline Мангистауская область & 0,17 \\
\hline Павлодарская область & 0,60 \\
\hline Северо-Казахстанская область & 0,63 \\
\hline Южно-Казахстанская область & 0,44 \\
\hline
\end{tabular}

Кроме того, по результатам исследования, в программном комплексе ArcGIS были составлены карты, отображающие значение индекса этнической мозаичности (см. рис. 1 и 2).

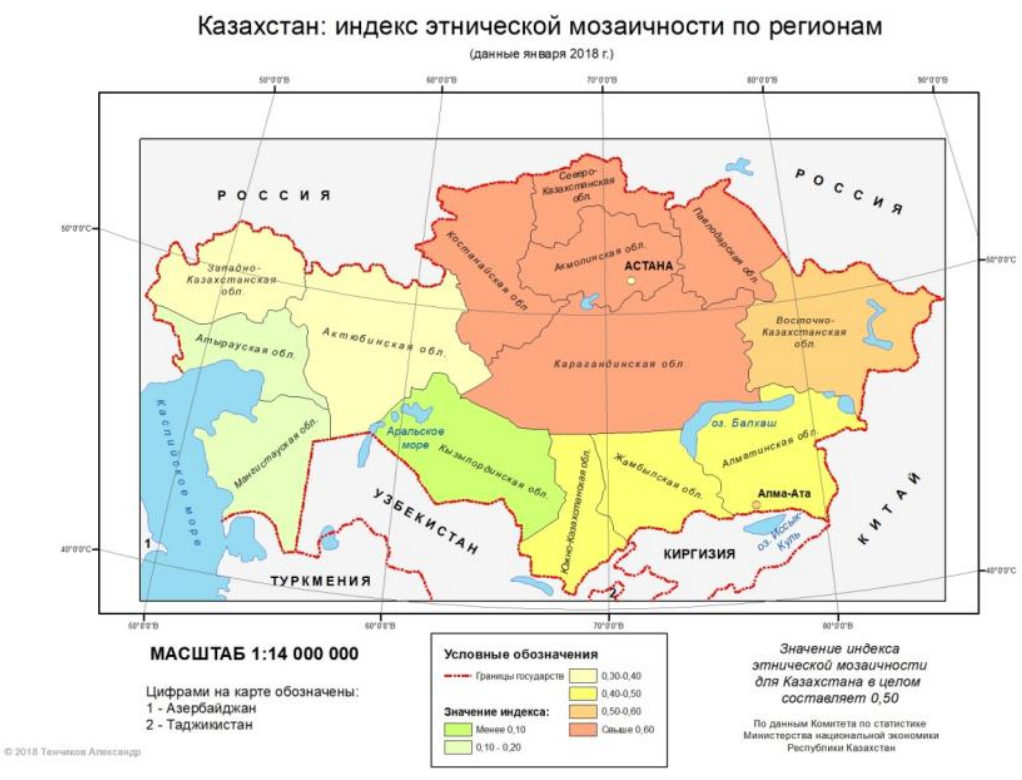

Рис. 1. Карта: Значение индекса этнической мозаичности по регионам Казахстана (2018 г.). Составлена автором 


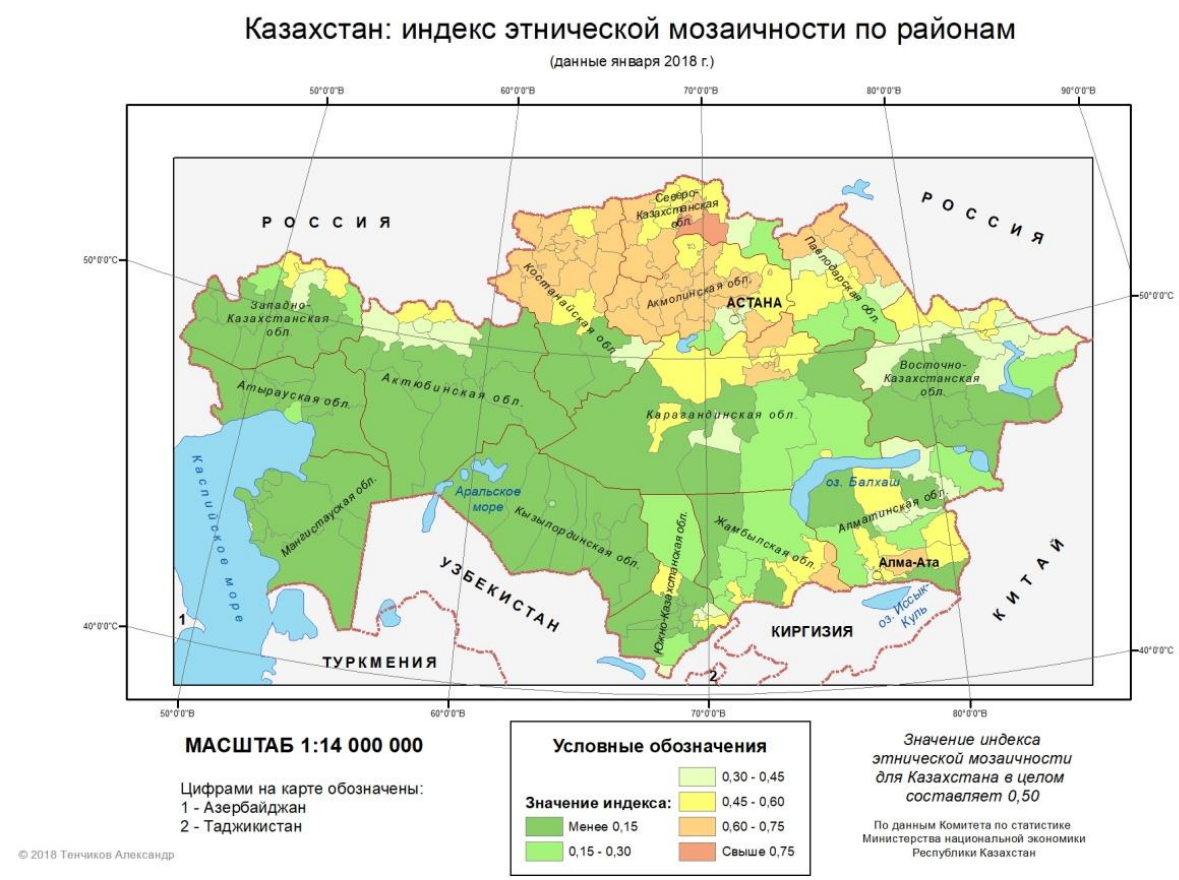

Рис. 2. Карта: Значение индекса этнической мозаичности по районам Казахстана (2018 г.). Составлена автором

Из этих карт хорошо видно, что наибольшее значение индекса этнической мозаичности характерно для северных областей и районов Казахстана. Также сильно выделяются юго-восточные районы, в то время как для большинства районов западных и юго-западных областей характерно низкое значение. В большинстве центральных районов Казахстана значение индекса также невелико.

Следует также дополнить, что одним из очевидных достоинств индекса этнической мозаичности является то, что его использование позволяет оценивать «вес» отдельных этнических групп в общей структуре населения. И поэтому этот коэффициент может также быть использован для оценки потенциала межэтнических конфликтов на исследуемой территории.

$$
* * *
$$

1. Эккель Б.М. Определение индекса мозаичности национального состава республик, краев и областей СССР // Советская этнография. - 1976. - № 2. - С. 33-42.

2. «Численность населения Республики Казахстан по отдельным этносам на начало 2018 года». Комитет по статистике Министерства национальной экономики Республики Казахстан. URL: stat.gov.kz/getImg?id=ESTAT260594 (проверено 09.10.2018). 